\title{
Characterization and Expression Profiling of Glutathione Peroxidase 1 gene (GPX1) and Activity of GPX in Onychostoma macrolepis suffered from Thermal Stress
}

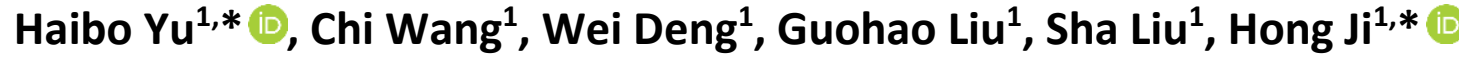 \\ ${ }^{1}$ Northwest A\&F University, College of Animal Science and Technology, Yangling 712100, China.
}

\begin{abstract}
How to cite
Yu, H., Wang, C., Deng, W., Liu, G., Liu, S., Ji, H. (2021). Characterization and Expression Profiling of Glutathione Peroxidase 1 gene (GPX1) and Activity of GPX in Onychostoma macrolepis suffered from Thermal Stress. Turkish Journal of Fisheries and Aquatic Sciences, 21, $541-551$. http://doi.org/10.4194/1303-2712-v21_11_02
\end{abstract}

\section{Article History}

Received 21 January 2021

Accepted 13 July 2021

First Online 14 July 2021

\section{Corresponding Author \\ Tel.: +862987092937 \\ E-mail: yuhaiboper@nwsuaf.edu.cn jihong@nwsuaf.edu.cn}

\author{
Keywords \\ Onychostoma macrolepis \\ GPX1 \\ Heat stress \\ Gene cloning \\ Gene expression
}

\begin{abstract}
In this study, full-length cDNA of glutathione peroxidases 1 (GPX1) of Onychostoma macrolepis was cloned by RACE, and expression of GPX1 and activity of GPX in $O$. macrolepis suffered from heat stress were analyzed. Compared with the control group $\left(24^{\circ} \mathrm{C}\right)$, the experimental fish were stressed for $0,1,3,6,12,24$, and 48 hours at the heated water $\left(30^{\circ} \mathrm{C}\right)$. Liver had highest level and response speed in GPX1 expression among various tissues after heat stress, indicated that liver was the highest sensitive tissue to heat stress. When the water was raised to the heating temperature $\left(30^{\circ} \mathrm{C}\right)$, the GPX activity decreased in fish serum, and the consumption of GPX eliminated the increase of ROS caused by heat stress within $3 \mathrm{~h}$. However, after $6 \mathrm{~h}$ and $12 \mathrm{~h}$ stress at $30^{\circ} \mathrm{C}, \mathrm{GPX}$ activity was significantly higher than that at $\mathrm{Oh}(\mathrm{P}<0.05)$, which is due to the rapid response of GPX to heat stress. In summary, fish showed a transient stress response and was acclimated to the new temperature after $24 \mathrm{~h}$ according to the overall expression of the GPX1 and the serum GPX activity, and both GPX1 and GPX play crucial roles in this process.
\end{abstract}

\section{Introduction}

Biotic and abiotic stresses can trigger dramatic increase of intracellular reactive oxygen species (ROS), including superoxide radicals, hydroxyl radicals and hydrogen peroxide (Fink \& Scandalios, 2002; Margis et al., 2008). Aerobic organisms have developed several non-enzymatic and enzymatic systems such as glutathione peroxidases (GPX), superoxide dismutases (SOD), catalases (CAT) and ascorbate peroxidases to neutralize these compounds (Fink \& Scandalios, 2002; Margis et al., 2008). Glutathione peroxidases (GPXs) are a family of antioxidant enzymes catalyzing the reduction of $\mathrm{H}_{2} \mathrm{O}_{2}$ or organic hydroperoxides, and regulate oxidative status together with other antioxidant enzymes (Apel \& Hirt, 2004). GPX1 is a vital component of the GPXs family (Toppo et al., 2008; Flohé \& BrigeliusFlohé, 2011). cDNA sequence of GPX1 has been reported in the rainbow trout (Oncorhynchus mykiss) (Pacitti et al., 2013), Antarctic fish Trematomus bernacchii (Sattin et al., 2015) and grass carp (Ctenopharyngodon idellus) (Li et al., 2008).

Onychostoma macrolepis belongs to the Cypriniformes, Cyprinidae, Barbinae, Onychostoma (Yu et al., 2017). In recent years, O. macrolepis has been becoming a cultured species in China due to its delicious taste and high content of docosahexaenoic acid (DHA) in muscle (Yu et al., 2017). Studies have been carried out in this species, focusing on artificial breeding, genetic diversity and nutritional requirement (Chen, 2007; Zhao et al., 2011), as well as bioinformation of some genes (Yang et al., 2014; Yu et al., 2017). However, there was 
no available information focusing on the gene information, molecular characterization and expression profiling of GPX1 in 0 . macrolepis to the present.

Water temperature is an important ecological factor that affect behavior, growth, metabolism, immune response, and survival of fish (Windisch et al., 2011; Makrinos \& Bowden, 2016; Dalvi et al., 2017). In nature, 0 . macrolepis commonly inhabits in mountain streams with relatively low temperature. Hence, water temperature is a key factor that affects the aquaculture of this species. O. macrolepis have an optimal growth temperature at $18^{\circ} \mathrm{C}-24^{\circ} \mathrm{C}$ (Chen, 2007), but they are usually exposed to high (over $30^{\circ} \mathrm{C}$ ) water temperature in the summer, which can trigger their oxidative stress and poor growth performance (Yu et al., 2017). Many studies reveal that fish can modulate their antioxidant system to adapt to the temperature changes (Cheng et al., 2015; Wang et al., 2016; Madeira et al., 2016; Yu et al., 2017). GPX1, as one of the most important parts of antioxidant system, might be a sensitive indicator and defense barrier in response to heat stress in $O$. macrolepis. However, nothing is known about the expression profiles of GPX1 and GPX activity changes of $O$. macrolepis after heat stress.

In this study, the full-length cDNA sequence of GPX1 from $O$. macrolepis was identified and its molecular sequence properties were characterized including phylogenetic analysis. Expression of GPX1 and activity of GPX in 0 . macrolepis after heat stress were also determined, aiming to provide insights into the role of GPX1 and GPX in antioxidant defense of $O$. macrolepis suffered from heat stress.

\section{Materials and Methods}

\section{Experimental Fish}

The fish was purchased from an aquaculture farm in Shaanxi Province, China. Before the start of the formal experiment, the experimental fish were acclimated at $24^{\circ} \mathrm{C}$ for two weeks. Fish are fed three times a day at $8: 00,12: 00$ and $17: 00$, with a $5 \%$ of body wet weight (Deng et al., 2020).

\section{Experimental Procedures and Sample Collection}

All the animal experiments and sampling procedures were approved by the Animal Care and Use Committee of Northwest A\&F University and performed in accordance with animal welfare and ethics (Approval No. DKZC2019053). After acclimation, experimental fish were fasted for $24 \mathrm{~h}$. One hundred forty-four fish individuals with the size of $19.5 \pm 0.9 \mathrm{~g}$ were distributed randomly into 8 groups. Each group contained three replicate tanks $(45 \times 25 \times 30 \mathrm{~cm})$ such that there were 6 fish in each tank. For heat stress, the temperature rose from $24{ }^{\circ} \mathrm{C}$ to $30{ }^{\circ} \mathrm{C}$ within 1 hour. The heat stress temperature $\left(30^{\circ} \mathrm{C}\right)$ was decided according to the temperature fluctuations that this fish species encounters in its natural habitat and the results of our previous study (Yu et al., 2017). The experimental fish of the control group were sampled at $24^{\circ} \mathrm{C}$. After stressed at $30^{\circ} \mathrm{C}$, fish were sampled at $0,1,3,6,12,24$ and 48 hours, respectively.

Aeration was continuously provided during the experiment to maintain the dissolved oxygen (DO) higher than $5.0 \mathrm{mg} \mathrm{L}^{-1}$. Water temperature was adjusted and maintained using auto-regulation induction heaters. $\mathrm{pH}$ was within the range of 7.2 to 7.8 . The parameters of the water quality were measured daily.

The experimental fish were anesthetized using tricaine methanesulfonate (MS-222, Sigma-Aldrich, USA) with the dose of $90 \mathrm{mg} \mathrm{L}^{-1}$ before sampling. A $2.5 \mathrm{ml}$ hypodermic syringe was used to collect blood samples from the tail vein ( 3 fish per fish). After standing at $4^{\circ} \mathrm{C}$ for 6 hours, the serum was centrifuged $(3,000 \times \mathrm{xg}, 10$ minutes, $4^{\circ} \mathrm{C}$ ). Thereafter, the serum samples of 3 fishes in the same tanks were pooled together. Tissues of 3 individuals were collected in each tank, including the heart, liver, kidney, spleen, gills, intestines and muscles, and pooled together at each sampling time point. The experimental samples were stocked at $-80^{\circ} \mathrm{C}$ until being analyzed.

\section{Cloning of Full-length GPX1 cDNA}

Total RNA was extracted from tissue samples using TRIzol Reagent (Invitrogen, USA) according to manufacturer's protocols. Integrity of RNA was checked by denaturing on agarose gel (1\%). Quantity and quality of extracted RNA was evaluated using a NanoDrop 2000 spectrophotometer (Thermo Fisher Scientific, Wilmington, DE, United States). The 260/280 nm absorbance ratio of all samples was above 1.8-2.0. Then, according to the manufacturer's method, first-strand cDNA was synthesized using relevant reagents (TaKaRa, Japan), and a partial cDNA sequence of its template GPX1 was amplified.

To amplify GPX1 partial cDNA sequence, primers (Table 1) were designed according to the available genes of other fish species, including grass carp (Ctenopharyngodon idella), silver carp (Hypophthalmichthys molitrix), zebrafish (Danio rerio) and Chinese rare minnow (Gobiocypris rarus). In order to obtain the full-length GPX1 sequence, the first cDNA was generated to quickly amplify the $5^{\prime} / 3^{\prime}$ cDNA ends according to the manufacturer's protocols of a SMARTer ${ }^{\mathrm{TM}}$ RACE cDNA Amplification Kit (Clontech, USA). The full-length GPX1 cDNA was obtained by using 5'/3'-RACE methods with gene specific primers designed based on the obtained partial sequence of GPX1 CDNA (Table 1). The PCR products were cloned into PMD18-T vector (Tiangen, China), and then inserted into $E$. coli strains. And positive clones were sequenced by Sangon Biotech (Shanghai, China). Finally, the partial sequence was assembled using contig Express application software. 
Table 1. Primers used in the present study

\begin{tabular}{lcc}
\hline Primer name & Primer sequence $\left(5^{\prime}-3^{\prime}\right)$ & Purpose \\
\hline GPX1-F & GTNCTNATTGARAATGTKGCGTC & Cloning \\
GPX1-R & AGGAACTTYTCAAAGTTCCAGG & Cloning \\
GPX1-R1 & TCGAAGCCATTTCCAGGA & $5^{\prime}$ RACE \\
GPX1-R2 & GACGGACTTCAGAGACAGCA & $5^{\prime}$ RACE \\
GPX1-F1 & TGTTCCTCAAGGAGAAGCTGCCTCA & $3^{\prime}$ RACE \\
GPX1-F2 & CGACTCTGCGTCCTTGATGGTTGAT & $3^{\prime}$ RACE \\
GPX1-real-F & AGGCACAACAGTCAGGGATT & qRT-PCR \\
GPX1-real-R & CGGACTTCAGAGACAGCAGA & qRT-PCR \\
B-Actin-F & TGACCCACACTGTACCCATC & qRT-PCR \\
B-Actin-R & CGGACAATTTCACTCTCGGC & qRT-PCR \\
\hline
\end{tabular}

Note: Genbank No.: GPX1, KY569541; 6-Actin, JN254630.1.

\section{Bioinformatics Analysis of GPX1}

The ORF Finder program (http://www.ncbi.nlm.nih.gov/gorf/gorf.htmL) was used to identify the ORF of GPX1. The online tool of ExPASy was used to conduct the protein analysis. The deduced GPX1 amino acids sequences of $O$. macrolepis were selected for multiple alignments with other organisms. The organisms include silver carp (Hypophthalmichthys molitrix) (ABU84810.1), Acrossocheilus fasciatus (Accession number: AIM56842.1), grass carp (Ctenopharyngodon idella) (ACF39780.1), crucian carp Carassius auratus (ABJ09418.1), zebra fish (Danio rerio) (NP_001007282.2), bighead carp Hypophthalmichthys nobilis (ACO53608.1), Bastard halibut Paralichthys olivaceus (ABU49600.1), Pacific bluefin tuna Thunnus orintalis (BAL41419.1), mefugu (Takifugu obscurus) (ACR20471.1), barred knifejaw (Oplegnathus fasciatus) (AAU44619.1), gilthead seabream (Sparus aurata) (AFY97790.1), human (Homo sapiens) (CAA68491.1), chicken (Gallus gallus) (NP_001264782.2), tropical clawed frog (Xenopus tropicalis) (NP_001015740.2), chimpanzees Pan troglodytes (NP_001070980.2), Bos Taurus (AAA16579.2), modern horses Equus caballus (NP_001159951.1), Mus musculus (CAA27558.1), Taeniopygia guttate (NP_001130041.1). The phylogenetic tree was generated by the neighborjoining method of the MEGA 6.0 program. The protein 3D model prediction was carried out on the online tools (http://www.expasy.org/) using SWISS MODEL online software.

\section{GPX1 Expression of 0 . macrolepis}

Primers used for RT-PCR were designed using the Primer Express 2.0 software (Applied Biosystems, Foster City, CA, USA) and listed in Table 1. All primers synthesized by Sangon Biotech (Shanghai, China). The housekeeping gene used for normalization of target gene was 8-actin (GenBank: JN254630.1). RT-PCR was conducted using a CFX 96 Real-Time PCR Detection System (Bio-Rad, Hercules, CA, USA). Three replicates were performed, and each total volume was $20 \mu \mathrm{L}$ containing $10 \mu \mathrm{L}$ of $2 \times \mathrm{SYBR}^{\circledR}$ Premix Ex Taq ${ }^{\mathrm{TM}}$ II (TaKaRa,
Dalian, PR China), $7.8 \mu \mathrm{L}$ of sterilized double-distilled water, $1 \mu \mathrm{L}$ of $1: 10$ diluted CDNA and $0.6 \mu \mathrm{L}$ of each forward and reverse primer. The RT-qPCR procedure including initial activation step at $95{ }^{\circ} \mathrm{C}$ for $3 \mathrm{~min}$, followed by 40 cycles of $95^{\circ} \mathrm{C}$ for $15 \mathrm{~s}$ and $60{ }^{\circ} \mathrm{C}$ for $30 \mathrm{~s}$, and $5 \mathrm{~s}$ at $65^{\circ} \mathrm{C}$. Melt-curve analysis was performed at the end of each run. All amplification efficiencies were ranged from $96 \%$ to $103 \%$. The comparative $\mathrm{Ct}$ method $2^{-\Delta \Delta C t}$ (Livak \& Schmittgen, 2001) was used to calculate the gene expression values and normalized with $\beta$-actin (Genbank No. JN254630.1).

\section{Activity of GPX in the Serum of 0 . macrolepis}

Activity of GPX was measured according to (Liu et al., 2013), using the Glutathione Peroxidase Assay Kit (Nanjing Jiancheng Bioengineering Institute, China). The activity of GPX was determined by measuring the oxidation rate of reduced glutathione (GSH) to oxidized glutathione (GSSG) form by $\mathrm{H}_{2} \mathrm{O}_{2}$ and the catalysis of GPX. The GPX activity was expressed as the GPX U. $\mathrm{mL}^{-1}$.

\section{Statistical Analysis}

The student's t test was used to analyze the difference of the control group $\left(24^{\circ} \mathrm{C}\right)$, compare to the experiment group at $30^{\circ} \mathrm{C}(\mathrm{Oh})$. Tukey adjustment was used to analyze the differences between groups of $30^{\circ} \mathrm{C}$ for $0,1,3,6,12,24$ and 48 hours through one-way analysis of variance (ANOVA). Prior to statistical analyses, raw data were diagnosed for normality of distribution and homogeneity of variance with the Kolmogorov-Smirnov test and Levene's test, respectively (Zar, 1999). Statistical analysis and graphs were performed by Prism 5 Software (Graph Pad, La Jolla, CA). $\mathrm{P}<0.05$ was considered significant for all tests.

\section{Results}

\section{Identification and Bioinformatic Analyses of GPX1 in o. macrolepis}

Full-length cDNA of GPX1 in 0 . macrolepis (Genbank accession No. KY569541) was cloned by means of RACE method. The full length of GPX1 of $O$. 
macrolepis is $915 \mathrm{bp}$, and it contains a 525bp open reading frame (ORF) and encodes 174 amino acids of putative peptide, with a theoretical pl of 5.92 and an estimated molecular weight of $16332.71 \mathrm{Da}$ (Figure 1). Multiple alignment of the deduced GPX1 amino acid sequences were conducted (Figure 2) and a phylogenetic tree was built (Figure 3). The deduced amino acid sequence of $O$. macrolepis GPX1 contained a signature motif 2 (LGAPCNQF) and a conserved active site motif (WNFEKF) (Figure 2). O. macrolepis GPX1 was grouped together with the GPX1 of other Cypriniformes species, forming an independent clade branched from Perciformes, Pleuronectiformes and Tetraodontiformes, as well as amphibians, avian and mammalian. The predicted three-dimensional (3D) structure of GPX1 was comparable with $5 \alpha$-helices and $2 \beta$-sheets (Figure 4).

\section{Expression of GPX1 in O. macrolepis Suffered from Heat Stress}

Tissue distribution of GPX1 expression in $O$. macrolepis was shown in Figure 5. The expression of GPX1 in the muscle, spleen, liver, intestine, kidney, gills and heart were tested. The highest expression level of GPX1 was observed in the liver, and the lowest expression level of GPX1 were observed in the gills, intestine and spleen $(P<0.05)$ (Figure 5).

Expression profiles of GPX1 of 0 . macrolepis suffered from heat stress was shown in Figure 6. After water rose to heating temperature $\left(30^{\circ} \mathrm{C}\right)$, expression level of GPX1 in liver, intestine and gills significantly increased $(P<0.05)$ (Figure 6$)$, but the expression level in muscle and heart decreased significantly $(P<0.05)$ (Figure 6). The response rate of GPX1 expression to heat stress varied in different tissues. The expression level of GPX1 reached its peak at 0 hours in the liver, 3 hours in the heart, spleen and gills, and 6 hours in the intestines and muscles after $30^{\circ} \mathrm{C}$ stress.

\section{Change in Activity of GPX in Serum of O. macrolepis Suffered from Heat Stress}

Variation of GPX activity in serum of $O$. macrolepis subjected to heat stress was shown in Figure 7. After the water was raised to the heating temperature $\left(30^{\circ} \mathrm{C}\right)$ for Oh, the GPX activity was found to be significantly decreased by testing the serum of $O$. macrolepis $(P<0.05)$. And after the water temperature was kept at $30^{\circ} \mathrm{C}$ for $1 \mathrm{~h}$, the GPX activity was found to be significantly decreased compared with $0 \mathrm{~h}$ by testing the serum of $O$. macrolepis $(P<0.05)$. Studies have shown that the GPX activity in serum gradually rises within 1 hour to 6 hours, and on the contrary, it gradually decreases within 6 hours to 48 hours. The hightest GPX activity in serum of $O$. macrolepis after stress at $30{ }^{\circ} \mathrm{C}$ was observed at $6 \mathrm{~h}(\mathrm{P}<0.05)$. Activity of GPX in serum of O. macrolepis after stressed at $30{ }^{\circ} \mathrm{C}$ for $24 \mathrm{~h}$ and $48 \mathrm{~h}$ significantly lower than that of $0 \mathrm{~h}(\mathrm{P}<0.05)$.

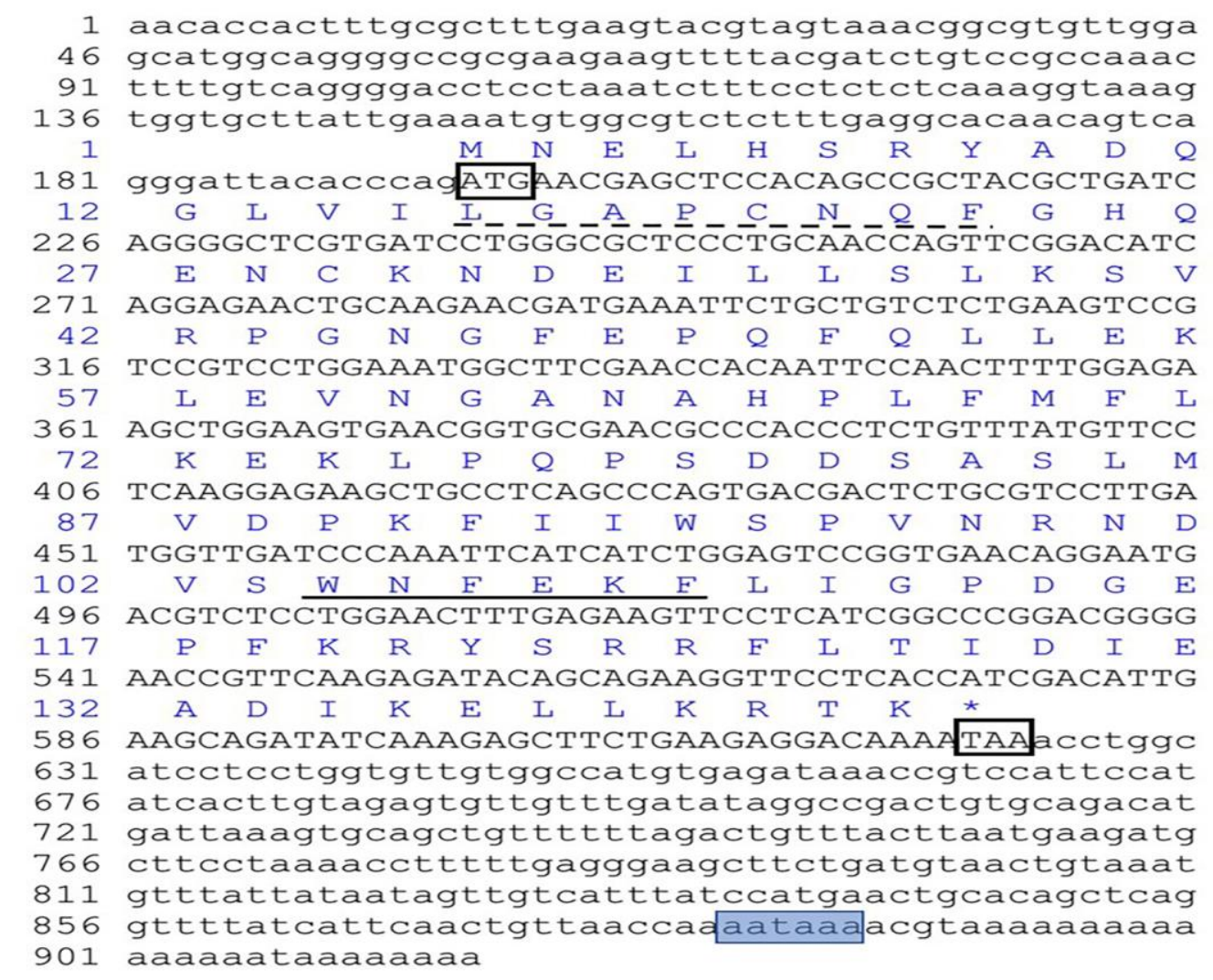

Figure 1. Nucleotide and deduced amino acid sequence of the GPX1 from $O$. macrolepis. The start codon, ATG and the stop codon, TGA are circled with black boxes. GPX signature motif 2 are marked with a dotted line, and conserved active site motif is underlined. 
Homo sapiens RCAARIAAAAAOSWVAFSARPLAGGEPVSLGSLRGKVLIIENVASIXGTTVRDVTOMNEIORRLGPR Pan troglodytes MCAARIAAAAAOSW AFSARPIAGGEPVSLGSLRGKVLIIENWASLUGTTVRDYTOMNELORRLGPR Equus caballus MCAAOLAAAARRSWYAFSARPIAGGEPISLGSLRGKVLIIENWASIUGTTVRDYTOMNELORRLGPR Mus musculus MCAARLSAAAOSTVYAFSARPITGGEPVSLGSIRGKVIIIENVASIXGTTIRDYTEMNDIOKRLGPR Taeniopygia guttata MAAAGAGAGAAR-LAELSAKPLGAAKPLSIGSLRGKVLIVVNVASIUGTTTRDFLOLNELQQRYGPR Gallus gallus MAATG---_LGIIARPLGAAEPIALSSIRGKVIIVUNVASIUGTTTRDFIOINELQORYGPR Acrossocheilus fasciatus MAGAAKK------FYDLSAKIISG-DLINESSLKGKVULVENVASLUGTTVRDYTOMNELHSRYADO Carassius auratus :-_-_-_-_-_-_

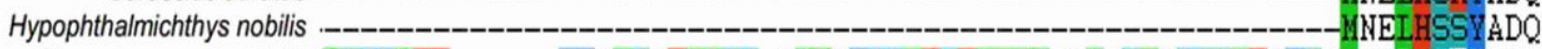
Ctenopharyngodon idella MTGTMKK-----FVDLSAKLISG-DLINFSSIKGKVVLIENVASIUGTTVRDYTOMNELHSCYADQ Hypophthalmichthys molitrix .--_.-Danio rerio MAGTKKR------EYDLSARLISG-DLINESSLKGKWVLIENVASIUGTTVRDVTOMNELHSRYADQ Takifugu obscurus MAGSVKK------FYELTAKLISG-EVLSFSALRGKVIIENVASIUGTTARDYTOMNELHGRYAAR Thunnus orientalis MAVRR--------FYDLTVKIISG-ETESISALKGKWULIENVASIUGTTTRDYTOMNELHSRYSD Oplegnathus fasciatus :-_-_-_-_-_-_ Sparus aurata MAGNVKR------EYALTANLLSG-EMFSFSALKGKVVLIENVASIUGTTTRDVTOMNELHSRYSDK
Paralichthys olivaceus Xenopus tropicalis MRLAMVS----RTVEFSARLISAGENTALSOYKGRVLIENVASIUGTTIRDYTOMSRLOSMYGPR

** : $: * *_{* * * * * * * * *}^{* *}: * * * \quad *: * * * *, *:: *::: * *: * * * \quad * * * *: *: \quad * * *$

Homo sapiens GLVULFPCNOFGHQENARNEEILNSLKYVRPGGFEPNFKLFERCEVNGAGAHPLFAFLREALPAPS Pan troglodytes GLVULGFPCNQFGHQNAKNEEIINSLKYVRGGGFEPNFWIFEKCEVNGAGAHPLFAFLREALAPS Equus caballus GLVULGPCNQF GHQENAKNEEIINSLKYVRPGGGEPNFTIFEKCEVNGAQAHPLFAFLREAPAPS Mus musculus GLVWLGFCNQFGHQENGKNEEILNSLKYURPGGGEEPNFTLFEKCEVNGERAHPLFTELRNALPTPS Taeniopygia guttata GLQULGFPCNQFGHQENGTNDEILPKIEHURPGNGVKPNETKEEKCEVNGKDAHPLFTFLKEALPFPH Gallus gallus GLRULFPCNQF GHQENATNEEILRSIEVURPGNGFKPNFTMFEKCEVNGKGAHPLFAFLREALPFPH Acrossocheilus fasciatus GLVILGAPCNQF GHQENCNDEILISLKYURPGNGEEREQLIEKIEVNGANAHPLFVELKEKLPQPS

Carassius auratus GIVULGAPCNQF GHOENTKNDEILISLKYURPGNGEENEQLIEKIEVNGVNAHPLFVELKEKIPQPS Hypophthalmichthys nobilis GLVILGAPCNQFGHQENCKDEILKSLKYVRPGNGFEPKEQLIEKIEVNGENAHPLFUFLKEKLPQPS Ctenopharyngodon idella GLVILGAPCNQF GHQENOKNDEILKSLKYURPGNGEEPKOLLEKIEVNGENAHPLFVFLKEKLPQPS Hypophthalmichthys molitrix GIVILGAPCNOFGHOENCKNDEILKSLKYVRPGDGEEPKSOLIEKIEVNGENAHPLFVELKEKLPQPS Danio rerio GLVWLGACNQFGQENCKNEILQSLKY YRPGNGEPKEQILEKIEVNGENAHPLFAFLKEKLPQPS

Onychostoma macrolepis GLVILGAPCNQFGHENCKNDEILISLKSURPGNGEEPQFQLIEKIEVNGANAHPLFMFLKEKLPQPS Takifugu obscurus GLVILGVPCNQFGHQENCKNDEIINSLKYVRPGGGFEPKEOLIEKVDVNGRNAHPLFVYLEKLPFPS Thunnus orientalis GLVILGUPCNOFGHOENCKNDEILRSIKYVRPGNGFEPNEQLIEKVDVNGKDAHPLFVYLKERLPSPC Oplegnathus fasciatus GLVILGUPCNQF GHQENCKNEEILKALKYVRPGNGFEPKEQLIEKVDVNGQDAHPLFVELKEKLPFPC Sparus aurata GLVIILUPCNOFGHQENCKNDEIIOSLKYVRPGNGEEPKIOLIEKVDVNGKDAHPLFVYLKEKLPFPS

Paralichthys olivaceus GLVILGPCNQFGHQENCKNEEILRCLKY VRPGNGEPKEQLIEKVDVNGKDAHPLFVYLNSLPFPS Xenopus tropicalis GLQULAFPCNQF GHOENSGNOEILNILKHVRPGGGEENEPLEEKVDVNGEKEHPIFTELKGOLPYPS

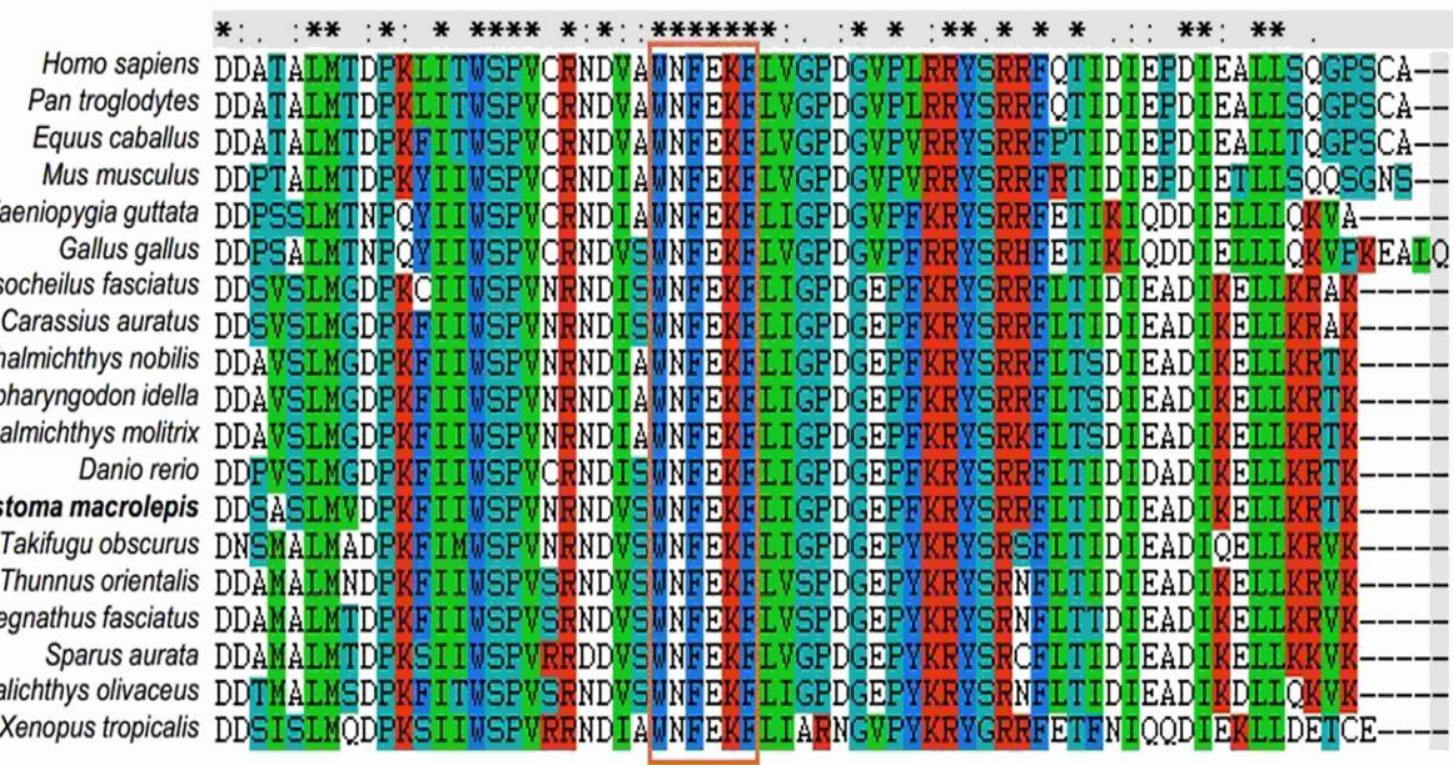

Figure 2. Multiple alignment of amino acid sequences between GPX1s from fish and other species. The GPX signature motif 2 is circled with red box and the conserved active site motif is circled with orange box. 


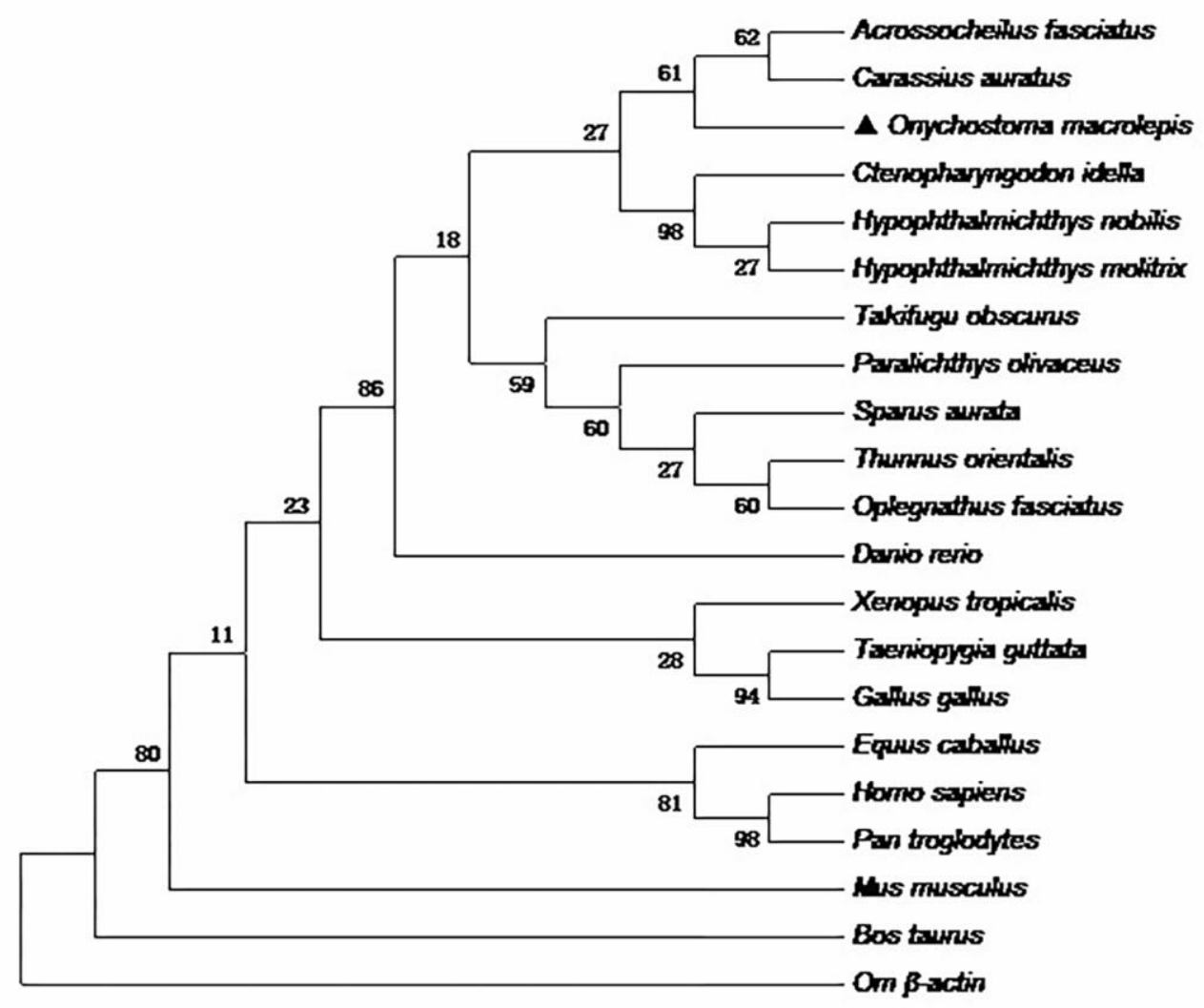

Figure 3. Phylogenetic tree of the deduced amino acid sequences of the GPX1.

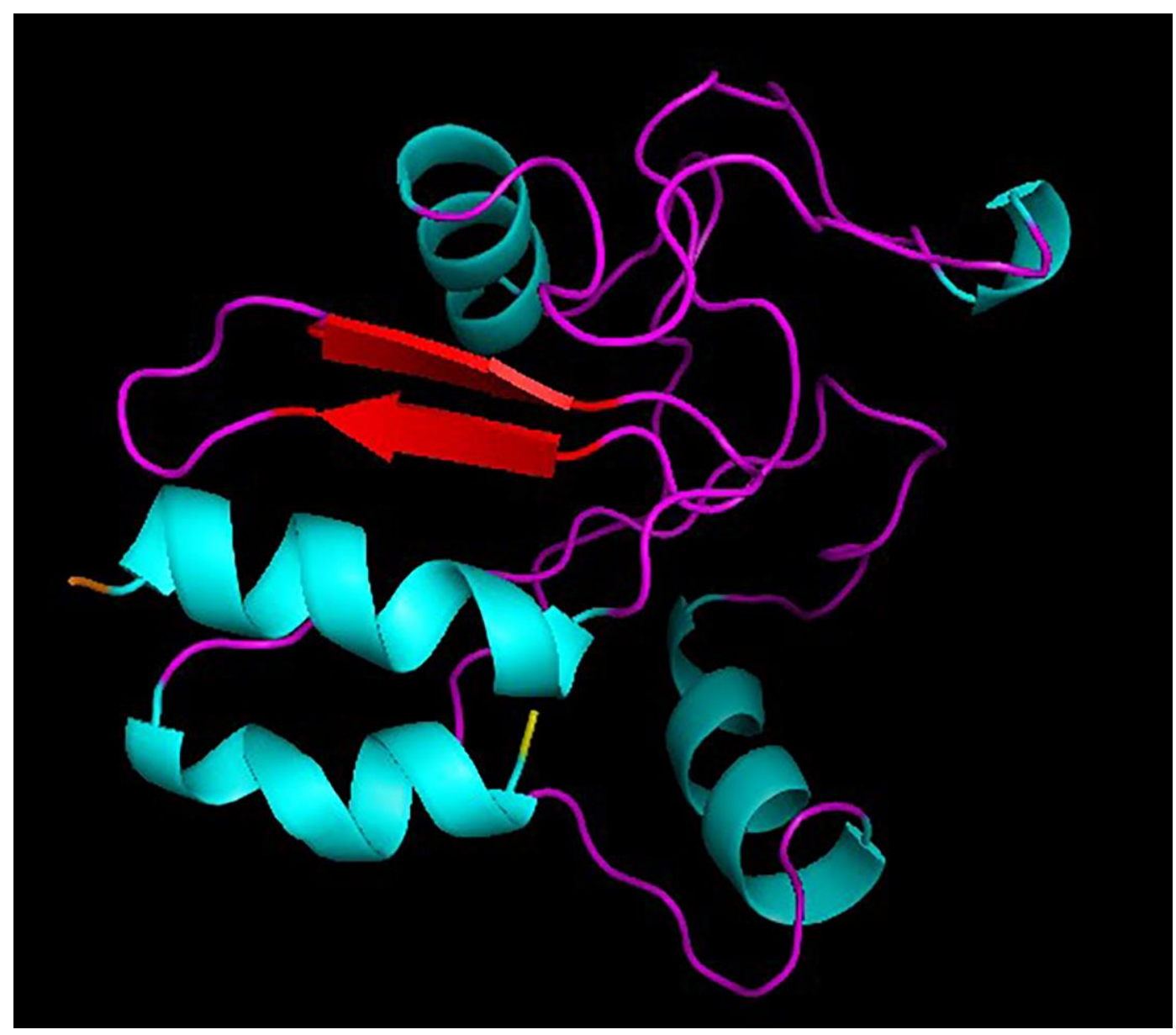

Figure 4. 3D structure of the GPX1 predicted by SWISS MODEL. 


\section{Discussion}

Identification and Bioinformatic Analyses of GPX1 in o. macrolepis

In this study, full-length cDNA of glutathione peroxidases 1 (GPX1) of $O$. macrolepis was firstly cloned by RACE method. GPX1 of $O$. macrolepis contains a 525bp ORF, and encodes 174 amino acids of putative peptide, with a estimated theoretical pl of 5.92 and an molecular weight of 16332.71 Da (Figure 1).The deduced amino acid sequence of GPX1 in 0 . macrolepis contained a signature motif 2 (LGAPCNQF) and a conserved active site motif (WNFEKF), which is consistent with the sequence of Cyprinidae species, including Acrossocheilus fasciatus, Carassius auratus, Hypophthalmichthys nobilis, Ctenopharyngodon Idella, Hypophthalmichthys molitrix and Danio rerio (Pacitti et al., 2013). To further confirm the identities of GPX1 of $O$. macrolepis and expound the phylogenetic relationship of GPX1 between species, multiple alignment of the deduced GPX1 amino acid sequences were conducted and a phylogenetic tree was built. O. macrolepis GPX1 was grouped together with the GPX1 of other Cypriniformes species, and form an independent clade branched from Perciformes, Pleuronectiformes and Tetraodontiformes, as well as avian, amphibians and mammalian. And the phylogeny of the selected organism is well reflected. The similar results were also found in other Cypriniformes species, inculding pengze crucian carp (Carassius auratus var. Pengze), grass carp (Ctenopharyngodon idella), bighead carp (Hypophthalmichthys nobilis) and silver carp (Hypophthalmichthys molitrix) (Li et al., 2008; Li et al., 2013).

\section{Expression of GPX1 in O. macrolepis in Response to Heat Stress}

Previous studies in many fish species showed that liver were the primary organ that expressesed antioxidant enzyme genes and antioxidant enzymes (Basha \& Rani, 2003; Albano, 2006; Kim et al., 2010; Sattin et al., 2015). In this study, tissue expression profiling revealed that liver had the highest expression level of GPX1 among the various tissues in O. macrolepis examined $(P<0.05)$ (Figure 5$)$. Similar result has been found that the liver of $O$. macrolepis had the highest expression level of the other antioxidant enzyme genes (such as CAT and Cu/Zn SOD) among the tissues (Yu et al., 2017). The results indicated that liver was a main place where oxidative stress occurs, and the antioxidant enzyme genes including GPX1 play an important role in liver antioxidant defense.

Heat stress generally led to excessive generation of ROS, which can result in oxidative damage in fish if not eliminated timely (Kaur et al., 2005; Cheng et al., 2015; Madeira et al., 2016). Previous studies found that the antioxidant system can eliminate the excessive ROS and it is one of the most important defense mechanism of sturgeon (Acipenser brevirostrum) and turbot (Scophthalmus maximus) when suffering heat stress (Gradil et al., 2014; Guerreiro et al., 2014). GPX1 is one of the stress responsive elements of the defense system against oxidative damage, and its expression could be affected by various stressors, including heat stress (Sattin et al., 2015). In this study, the key role of GPX1 in liver intestine and gills in the body's response to heat stress was shown. This is because the expression of GPX1 in these tissues increased significantly after exposed to the heated water $\left(30^{\circ} \mathrm{C}\right)(\mathrm{P}<0.05)$ (Figure 6).

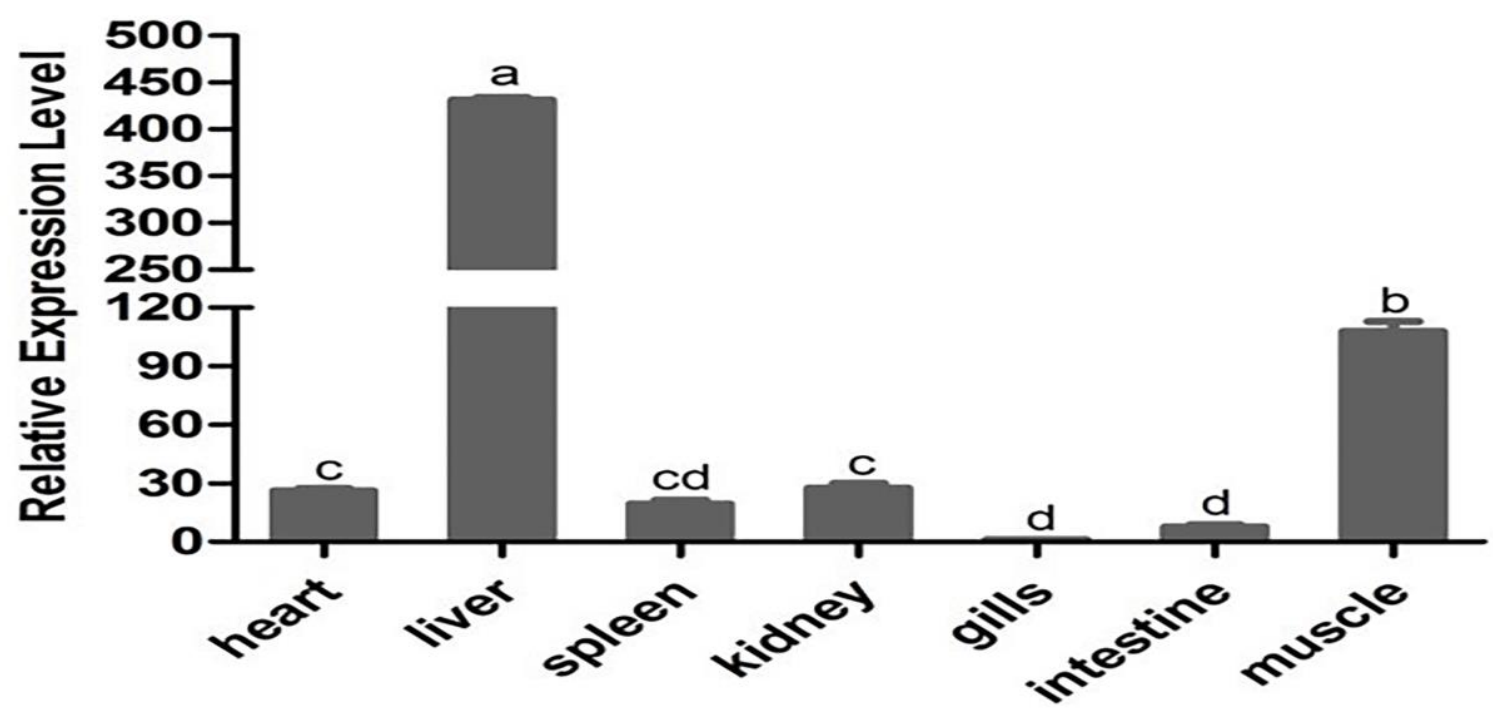

Figure 5. Tissue distribution of GPX1 of the $O$. macrolepis cultured at $24^{\circ} \mathrm{C}$. The values $(n=3)$ were expressed as mean $\pm \operatorname{SEM}$. 
Heart

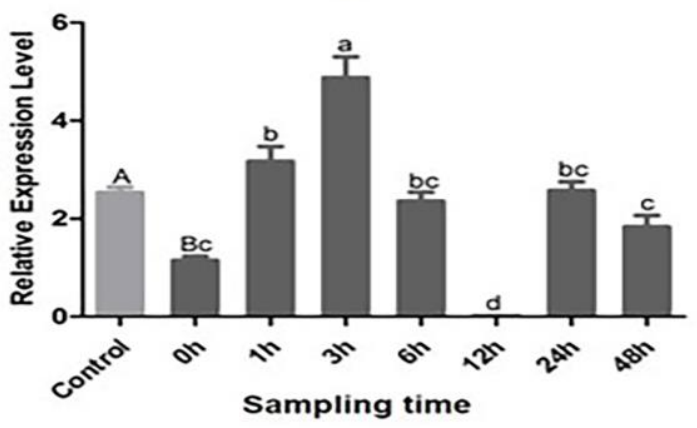

Spleen

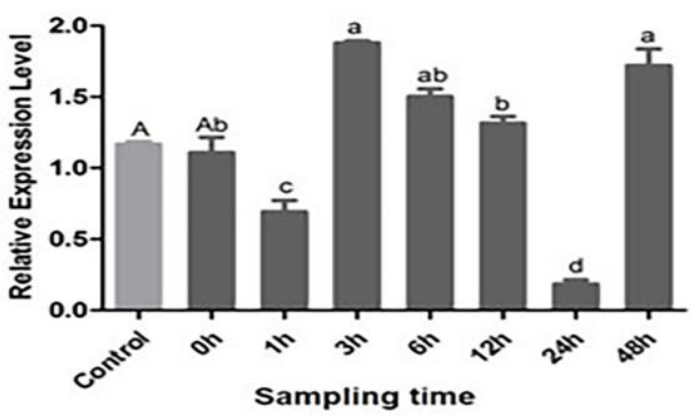

Intestine

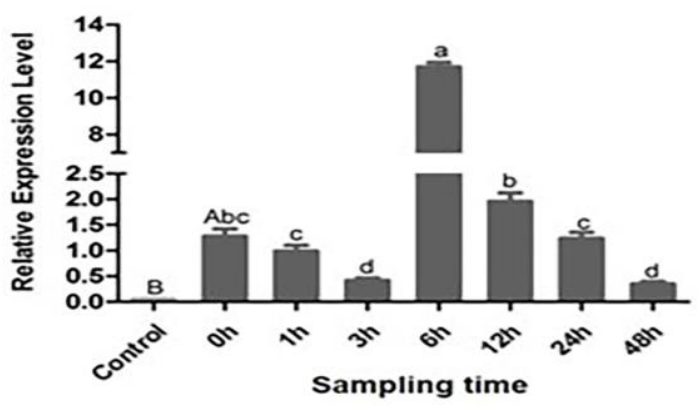

Liver

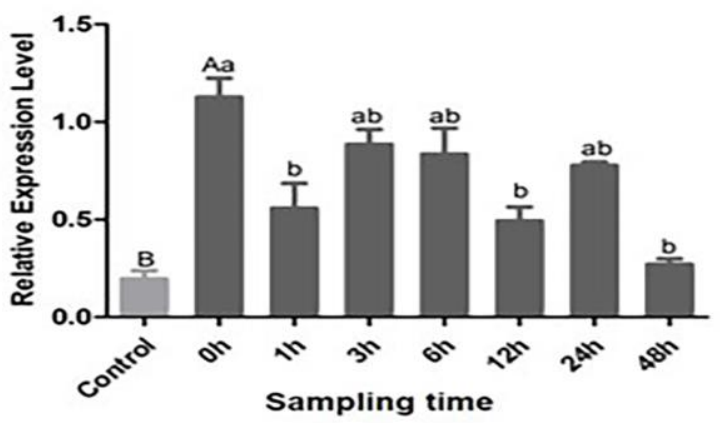

Muscle

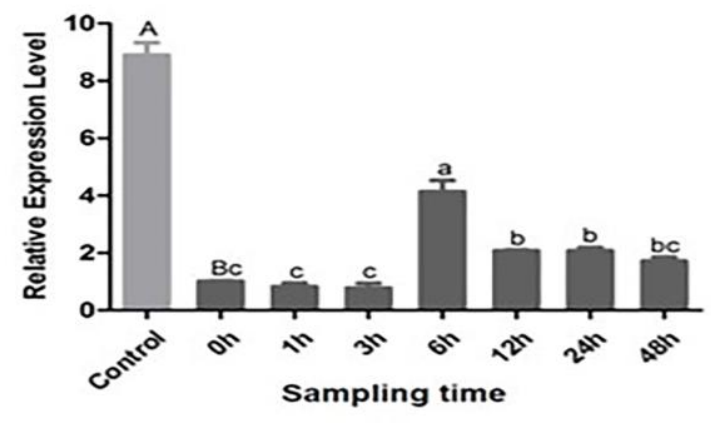

Gills

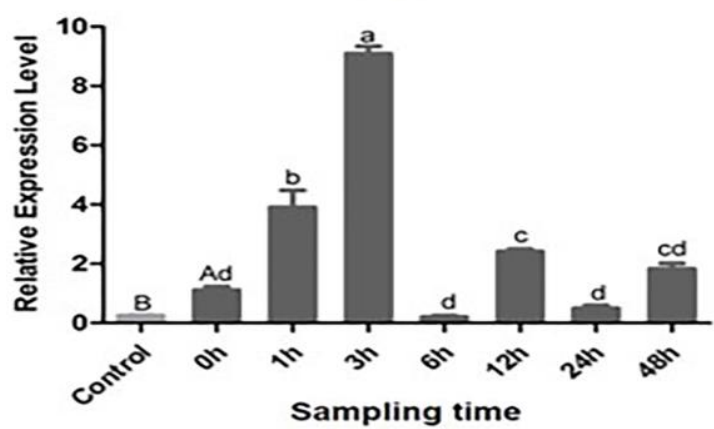

Figure 6 Relative expression of the GPX1 in different tissues of $O$. macrolepis in response to heat stress. The values $(n=3)$ were expressed as mean $\pm \mathrm{SEM}$. For different capital letter means different between control $\left(24^{\circ} \mathrm{C}\right)$ and $\mathrm{Oh}\left(30^{\circ} \mathrm{C}\right)$ groups. For different lowercase letter means different among $0 \mathrm{~h}, 1 \mathrm{~h}, 3 \mathrm{~h}, 6 \mathrm{~h}, 12 \mathrm{~h}, 24 \mathrm{~h}$ and $48 \mathrm{~h}$ groups. The gene expression level of all groups were converted to relative expression level according to the expression level in $1 \mathrm{~h}$ group, which mean the relative expression level in $1 \mathrm{~h}$ group was $\sim 1$. For all tests, $P<0.05$ was considered significant.

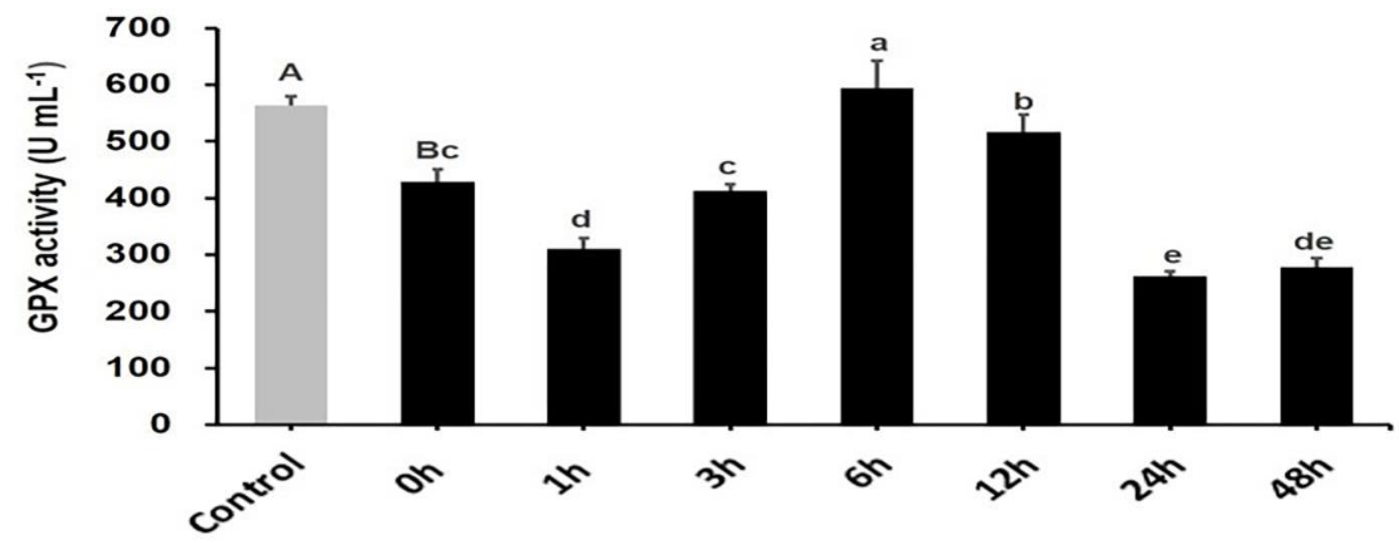

Figure 7 Change in activity of GPX in the serum 0 . macrolepis in response to heat stress. The values $(n=3)$ were expressed as mean $\pm \mathrm{SD}$. For different capital letter means different between control $\left(24^{\circ} \mathrm{C}\right)$ and $0 \mathrm{~h}$ groups. For different lowercase letter means different among $0 \mathrm{~h}, 1 \mathrm{~h}, 3 \mathrm{~h}, 6 \mathrm{~h}, 12 \mathrm{~h}, 24 \mathrm{~h}$ and $48 \mathrm{~h}$ groups. For all tests, $P<0.05$ was considered significant. 
Similar result was also found in pufferfish (Takifugu obscurus) (Cheng et al., 2015) in which high water temperature significantly induced mRNA expression of antioxidant enzyme genes including GPX.

In addition, the quick response in expression of GPX1 is important in antioxidant defense processes of fish suffer from heat stress. In this study, the speed of response to heat stress varied in different tissues in terms of GPX1 expression. The expression level of GPX1 reached its peak at 0 hours in the liver, 3 hours in the heart, spleen and gills, and 6 hours in the intestines and muscles after $30^{\circ} \mathrm{C}$ stress. Liver had the highest response speed of GPX1 expression to heat stress among the tissues examined, indicating that liver was the highly sensitive tissue in response to heat stress. The above results showed that the liver had the highest level and response speed of GPX1 expression. This is reasonable as liver is a key organ of ROS generation (Albano, 2006) so that high stock and quick generation of antioxidant is required to protect this organ against lipid peroxidation induced by heat stress.

Interestingly, our previous studies have shown that the mRNA level of $\mathrm{Cu} / \mathrm{Zn}$-SOD reaches its peak in most tissues of $O$. macrolepis after 24 hours of stress at $30^{\circ} \mathrm{C}$ (Yu et al., 2017). However, in this study, expression of GPX1 can respond quickly to heat stress at $30{ }^{\circ} \mathrm{C}$ within $6 \mathrm{~h}$, though the response speed varied in different tissues. These results indicated that expression response of GPX1 to heat stress was more prompt compared to $\mathrm{Cu} / \mathrm{Zn}-\mathrm{SOD}$ in $O$. macrolepis. Up-regulation of GPX1 might strengthen the antioxidant defense of $O$. macrolepis suffered from heat stress at the early stages (within $6 \mathrm{~h}$ ).

\section{Change in Activity of GPX in Serum of $O$. macrolepis Suffered from Heat Stress}

Many previous study selected activity of antioxidant enzyme in serum as a indicator to evaluate the antioxidant status of fish (Jiang et al., 2009; Tang et al., 2016; Yu et al., 2017). Therefore, in this serum study of $O$. macrolepis, the activity of GPX in heat stress was determined. When temperature rose to the $30^{\circ} \mathrm{C}(0 \mathrm{~h})$, it indicated that the GPX activity decreased significantly from the results of the serum study from $563.6 \pm 16.3 \mathrm{U}$ $\mathrm{mL}^{-1}$ to $429.0 \pm 22.3 \mathrm{U} \mathrm{mL}^{-1}(\mathrm{P}<0.05)$, and kept decreasing within $3 \mathrm{~h}$ after stressed at $30{ }^{\circ} \mathrm{C}$. Decrease of GPX activity at early stages (within $3 \mathrm{~h}$ ) of heat stress might be due to consumption of GPX to eliminate the overproduced ROS caused by heat stress. Similar result was also found by Kaur et al. (2011) in which GPX activity decreased significantly in liver, kidney and gills of Channa punctata Bloch with $3 \mathrm{~h}$ heat stress $\left(32{ }^{\circ} \mathrm{C}\right)$ compared to control group $\left(20^{\circ} \mathrm{C}\right)$.

After stressed at $30{ }^{\circ} \mathrm{C}, G P X 1$ transcription was rapidly activated within $6 \mathrm{~h}$ to synthesize new GPX to eliminate excessive ROS. But, increase of GPX activity in the serum was observed from $6 \mathrm{~h}$ to $12 \mathrm{~h}$ after stressed at $30{ }^{\circ} \mathrm{C}$. This unsynchronized changes in gene expression and enzyme activity might be due to lag of translation to transcription, and many previous studies have found that there was a time window between transcription and translation (Amado et al., 2011; Kong et al., 2017; Yu et al., 2017). In addition, some enzyme or proteins are also subjected to post-transcriptional regulation, which might lead to the lack of similarity between mRNA levels and enzyme activity (Hansen et al., 2007). With the continuous transcription and translation, the levels of GPX were recovered after stressed at $30{ }^{\circ} \mathrm{C}$ from $6 \mathrm{~h}$ to $12 \mathrm{~h}$, indicating an enhanced antioxidant capacity of $O$. macrolepis to the short-term heat stress. Interestingly, compared to the 0 $h$, it was found that the activity of GPX decreased significantly by testing the serum after stressed at $30^{\circ} \mathrm{C}$ for $24 \mathrm{~h}$ and $48 \mathrm{~h}(\mathrm{P}<0.05)$, which may because of the adaption of $O$. macrolepis to the elevated temperature.

In conclusion, a 915 bp GPX1 cDNA was cloned from $O$. macrolepis, which encodes a protein consisting of 174 amino acids. The liver had the highest level and response speed in GPX1 expression among various tissues in response to heat stress, indicated that liver was the highest sensitive tissue in response to heat stress, and the GPX1 plays a crucial role in defense of oxidative stress resulted from heat stress in liver. GPX activity in the serum declined after exposed to the heated water at $30{ }^{\circ} \mathrm{C}(0 \mathrm{~h})$, and kept decreasing within $3 \mathrm{~h}$, which may be due to the over consumption of GPX for eliminating the increased ROS caused by heat stress. However, compared with $0 \mathrm{~h}, \mathrm{GPX}$ activity increased significantly after $6 \mathrm{~h}$ and $12 \mathrm{~h}$ at the heated water, due to its rapid response to heat stress. It appeared that the fish showed a transient stress response and was acclimated to the new temperature after $24 \mathrm{~h}$ according to the overall expression of the GPX1 and the serum GPX activity, and both GPX1 and GPX play crucial roles in this process. However, further study on the expression response of GPX1 and GPX to a longer term heat stress also needs to be addressed in the future.

\section{Ethical Statement}

Not applicable.

\section{Funding Information}

This research was funded by Youth Talent Cultivation Program of Northwest A\&F University (2452018030), Science and Technology Research Program of China Se-enriched Research Institute (2018FXZX02-05), and Technical Innovation Guidance Project of Shaanxi Province (2019QYPY-124).

\section{Author Contribution}

HY: Methodology; Investigation; Formal analysis, Roles/Writing - original draft, Funding acquisition; Project administration; Supervision. CW: Writing - 
review \& editing, Investigation. WD: Formal analysis; Investigation. GL: Investigation. SL: Investigation. HJ: Methodology; Project administration; Supervision.

\section{Conflict of Interest}

The authors declare that they have no known competing financial interests or personal relationships that could have appeared to influence the work reported in this paper.

\section{References}

Albano, E. (2006). Alcohol, oxidative stress and free radical damage. Proceedings of the Nutrition Society, 65(3), 278-290. https://doi.org/10.1079/PNS2006496

Amado, L.L., Garcia, M.L., Pereira, T.C., Yunes, J.S., Bogo, M.R., Monserrat, J.M. (2011). Chemoprotection of lipoic acid against microcystin-induced toxicosis in common carp (Cyprinus carpio, Cyprinidae). Comparative Biochemistry and Physiology C-Toxicology \& Pharmacology, 154(3), 146-153. https://doi.org/10.1016/j.cbpc.2011.04.007

Apel, K., \& Hirt, H. (2004). Reactive oxygen species: metabolism, oxidative stress, and signal transduction. Annual Review of Plant Biology, 55, 373399.https://doi.org/10.1146/annurev.arplant.55.03190 3.141701

Basha, P.S., \& Rani, A.U. (2003). Cadmium-induced antioxidant defense mechanism in freshwater teleost Oreochromis mossambicus (Tilapia). Ecotoxicology and Environmental Safety, 56(2), 218-221. https://doi.org/10.1016/S01476513(03)00028-9

Cheng, C.H., Yang, F.F., Liao, S.A., Miao, Y.T., Ye, C.X., Wang, A.L., Tan, J.W., Chen, X.Y. (2015). High temperature induces apoptosis and oxidative stress in pufferfish (Takifugu obscurus) blood cells. Journal of Thermal Biology, 53, 172-179. https://doi.org/10.1016/j.jtherbio.2015.08.002

Chen, C. (2007). The ecological habits and development, and utilization of Onychostoma macrolepis. Shandong Fisheries.

Dalvi, R.S., Das, T., Debnath, D., Yengkokpam, S., Baruah, K., Tiwari, L.R., Pal, A.K. (2017). Metabolic and cellular stress responses of catfish, Horabagrus brachysoma (Günther) acclimated to increasing temperatures. Journal of Thermal Biology, 65, 32-40. https://doi.org/10.1016/j.jtherbio.2017.02.003

Deng, W., Jian, S., Chang, Z.G., Gou, N.N., Wu, W.Y., Luo, X.L., Zhou, J.S., Yu, H.B., Ji, H. (2020). Energy response and fatty acid metabolism in Onychostoma macrolepis exposed to low-temperature stress. Journal of Thermal Biology, 94, 0306-4565.

https://doi.org/10.1016/j.jtherbio.2020.102725

Fink, R.C., \& Scandalios, J.G. (2002). Molecular evolution and structure-function relationships of the superoxide dismutase gene families in angiosperms and their relationship to other eukaryotic and prokaryotic superoxide dismutases. Archives of Biochemistry and Biophysics, 399(1), 19-36. https://doi.org/10.1006/abbi.2001.2739

Flohé, L., \& Brigelius-Flohé, R. (2011). Selenoproteins of the glutathione peroxidase family. Selenium. Springer.

Gradil, A.M., Wright, G.M., Speare, D.J., Wadowska, D.W., Purcell, S., Fast, M.D. (2014). The effects of temperature and body size on immunological development and responsiveness in juvenile shortnose sturgeon (Acipenser brevirostrum). Fish \& Shellfish Immunology, 40(2), 545-555. https://doi.org/10.1016/j.fsi.2014.07.036

Guerreiro, I., Pérez-Jiménez, A., Costas, B., Oliva-Teles, A. (2014). Effect of temperature and short chain fructooligosaccharides supplementation on the hepatic oxidative status and immune response of turbot (Scophthalmus maximus). Fish \& Shellfish Immunology, 40(2), 570-576.

https://doi.org/10.1016/j.fsi.2014.08.017

Hansen, B.H., Rømma, S., Garmo, Ø.A., Pedersen, S.A., Olsvik, P.A., Andersen, R.A. (2007). Induction and activity of oxidative stress-related proteins during waterborne $\mathrm{Cd} / \mathrm{Zn}$-exposure in brown trout (Salmo trutta). Chemosphere, 67(11), 2241-2249.

https://doi.org/10.1016/j.chemosphere.2006.12.048

Jiang, W.D., Feng, L., Liu, Y., Jiang, J., Zhou, X.Q. (2009). Myo inositol prevents oxidative damage, inhibits oxygen radical generation and increases antioxidant enzyme activities of juvenile Jian carp (Cyprinus carpio var. Jian). Aquaculture Research, 40(15), 1770-1776. https://doi.org/10.1111/j.1365-2109.2009.02283.x

Kaur, M., Atif, F., Ansari, R.A., Ahmad, F., Raisuddin, S. (2011). The interactive effect of elevated temperature on deltamethrin-induced biochemical stress responses in Channa punctata Bloch. Chemico-Biological Interactions, 193(3), 216-224. https://doi.org/10.1016/j.cbi.2011.06.011

Kim, J.H., Rhee, J.S., Lee, J.S., Dahms, H.U., Lee, J., Han, K.N., Lee, J.S. (2010). Effect of cadmium exposure on expression of antioxidant gene transcripts in the river pufferfish, Takifugu obscurus (Tetraodontiformes). Comparative Biochemistry and Physiology C-Toxicology \& Pharmacology, 152(4), 473-479. https://doi.org/10.1016/j.cbpc.2010.08.002

Kong, X., Qiao, D., Zhao, X., Wang, L., Zhang, J., Liu, D., Zhang, $H$. (2017). The molecular characterizations of $\mathrm{Cu} / \mathrm{ZnSOD}$ and MnSOD and its responses of mRNA expression and enzyme activity to Aeromonas hydrophila or lipopolysaccharide challenge in Qine crucian carp Carassius auratus. Fish \& Shellfish Immunology, 67, 429440. https://doi.org/10.1016/j.fsi.2017.06.031

Li, G.Z., Liang, X.F., Yao, W., Liao, W.Q., Zhu, W.F. (2008). Molecular characterization of glutathione peroxidase gene from the liver of silver carp, bighead carp and grass carp. BMB Reports, 41(3), 204-209. https://doi.org/10.5483/bmbrep.2008.41.3.204

Li, M., Zheng, Y., Liang, H., Zou, L.H., Sun, J., Zhang, Y., Qin, F., Liu, S., Wang, Z. (2013). Molecular cloning and characterization of cat, gpx1 and $\mathrm{Cu} / \mathrm{Zn}$-sod genes in pengze crucian carp (Carassius auratus var. Pengze) and antioxidant enzyme modulation induced by hexavalent chromium in juveniles. Comparative Biochemistry and Physiology C-Toxicology \& Pharmacology, 157(3), 310321. https://doi.org/10.1016/j.cbpc.2013.02.003

Liu, L., Liu, Y., Cui, J., Liu, H., Liu, Y.B., Qiao, W.L., Sun, H., Yan, C.D. (2013). Oxidative stress induces gastric submucosal arteriolar dysfunction in the elderly. World Journal of Gastroenterology, 19(48), 9439-9446. https://dx.doi.org/10.3748\%2Fwjg.v19.i48.9439

Livak, K.J., \& Schmittgen, T.D. (2001). Analysis of relative gene expression data using real-time quantitative PCR and the 
2- $\Delta \Delta \mathrm{CT} \quad$ method. Methods, 25(4), 402-408. https://doi.org/10.1006/meth.2001.1262

Madeira, D., Vinagre, C., Diniz, M.S. (2016). Are fish in hot water? Effects of warming on oxidative stress metabolism in the commercial species Sparus aurata. Ecological Indicators, 63, 324-331. https://doi.org/10.1016/j.ecolind.2015.12.008

Makrinos, D.L., \& Bowden, T.J. (2016). Natural environmental impacts on teleost immune function. Fish \& Shellfish Immunology, 53, 50-57. https://doi.org/10.1016/j.fsi.2016.03.008

Margis, R., Dunand, C., Teixeira, F.K., Margis-Pinheiro, M. (2008). Glutathione peroxidase family-an evolutionary overview. FEBS Journal, 275(15), 3959-3970. https://doi.org/10.1111/j.1742-4658.2008.06542.x

Pacitti, D., Wang, T., Page, M.M., Martin, S.A.M., Sweetman, J., Feldmann, J., Secombes, C.J. (2013). Characterization of cytosolic glutathione peroxidase and phospholipidhydroperoxide glutathione peroxidase genes in rainbow trout (Oncorhynchus mykiss) and their modulation by in vitro selenium exposure. Aquatic Toxicology, 130, 97111. https://doi.org/10.1016/j.aquatox.2012.12.020

Sattin, G., Bakiu, R., Tolomeo, A.M., Carraro, A., Coppola, D., Ferro, D., Patarnello, T., Santovito, G. (2015). Characterization and expression of a new cytoplasmic glutathione peroxidase 1 gene in the Antarctic fish Trematomus bernacchii. Hydrobiologia, 761(1), 363-372. https://doi.org/10.1007/s10750-015-2488-6

Tang, X.L., Fu, J.H., Li, Z.H., Fang, W.P., Yang, J.Y., Zou, J.X. (2016). Effects

https://doi.org/10.1016/j.aquatox.2012.12.020of a dietary administration of purple coneflower (Echinacea purpurea) on growth, antioxidant activities and 8 mi RNA $s$ expressions in crucian carp (Carassius auratus). Aquaculture Research, 47(5), 1631-1638. https://doi.org/10.1111/are.12624
Toppo, S., Vanin, S., Bosello, V., Tosatto, S.C. (2008). Evolutionary and structural insights into the multifaceted glutathione peroxidase (Gpx) superfamily. Antioxidants \& Redox Signaling, 10(9), 1501-1514. https://doi.org/10.1089/ars.2008.2057

Wang, Y., Liu, Z., Li, Z., Shi, H., Kang, Y., Wang, J., Huang, J., Jiang, L. (2016). Effects of heat stress on respiratory burst, oxidative damage and SERPINH1 (HSP47) mRNA expression in rainbow trout Oncorhynchus mykiss. Fish Physiology and Biochemistry, 42(2), 701-710. https://doi.org/10.1007/s10695-015-0170-6

Windisch, H.S., Kathöver, R., Pörtner, H.O., Frickenhaus, S., Lucassen, M. (2011). Thermal acclimation in Antarctic fish: transcriptomic profiling of metabolic pathways. American Journal of Physiology-Regulatory Integrative and Comparative Physiology, 301(5), R1453R1466. https://doi.org/10.1152/ajpregu.00158.2011

Yang, X., Xu, S., Li, W., Yuan, D., Ma, S. (2014). Characterization of Gene Expression of Fatty Acid Binding Proteins (FABP) in Largescale Shoveljaw Fish (Onychostoma macrolepis). International Journal of Bioscience, Biochemistry and Bioinformatics, 4(2), 125. https://doi.org/10.7763/IJBBB.2014.V4.324

Yu, H., Deng, W., Zhang, D., Gao, Y., Yang, Z., Shi, X., Sun, J., Zhou, J., Ji, H. (2017). Antioxidant defenses of Onychostoma macrolepis in response to thermal stress: insight from mRNA expression and activity of superoxide dismutase and catalase. Fish \& Shellfish Immunology, 66, 50-61. https://doi.org/10.1016/j.fsi.2017.04.027

Zar, J.H. (1999). Biostatistical analysis. Pearson Education India.

Zhao, Y.H., Gozlan, R.E., Zhang, C.G. (2011). Out of sight out of mind: current knowledge of Chinese cave fishes. Journal of Fish Biology, 79(6), 1545-1562.

https://doi.org/10.1111/j.1095-8649.2011.03066.x 